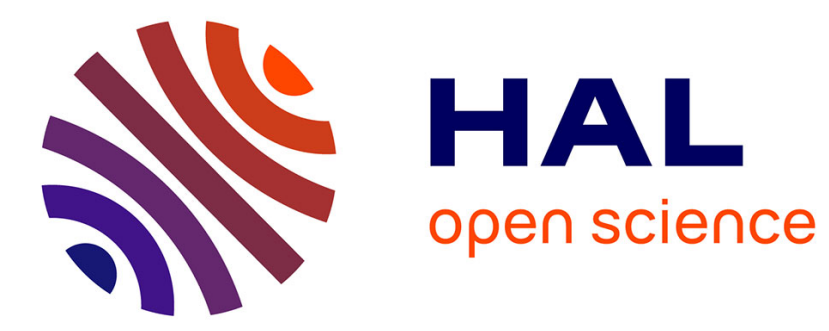

\title{
Ultra compact High responsivity photodiodes for $>100$ Gbaud applications
}

C Caillaud, H Bertin, A Bobin, R Gnanamani, N Vaissiere, F Pommereau, J Decobert, C Maneux

\section{- To cite this version:}

C Caillaud, H Bertin, A Bobin, R Gnanamani, N Vaissiere, et al.. Ultra compact High responsivity photodiodes for $>100$ Gbaud applications. ECOC 2021, Sep 2021, Bordeaux, France. hal-03350750

\author{
HAL Id: hal-03350750 \\ https://hal.science/hal-03350750
}

Submitted on 21 Sep 2021

HAL is a multi-disciplinary open access archive for the deposit and dissemination of scientific research documents, whether they are published or not. The documents may come from teaching and research institutions in France or abroad, or from public or private research centers.
L'archive ouverte pluridisciplinaire HAL, est destinée au dépôt et à la diffusion de documents scientifiques de niveau recherche, publiés ou non, émanant des établissements d'enseignement et de recherche français ou étrangers, des laboratoires publics ou privés. 


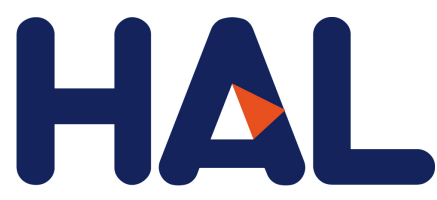

archives-ouvertes

\section{Ultra compact High responsivity photodiodes for $>100$ Gbaud applications}

C Caillaud, H Bertin, A Bobin, R Gnanamani, N Vaissiere, F Pommereau, J Decobert, C Maneux

\section{To cite this version:}

C Caillaud, H Bertin, A Bobin, R Gnanamani, N Vaissiere, et al.. Ultra compact High responsivity photodiodes for $>100$ Gbaud applications. ECOC 2021, Sep 2021, Bordeaux, France. hal-03350750

\section{HAL Id: hal-03350750 \\ https://hal.archives-ouvertes.fr/hal-03350750}

Submitted on 21 Sep 2021

HAL is a multi-disciplinary open access archive for the deposit and dissemination of scientific research documents, whether they are published or not. The documents may come from teaching and research institutions in France or abroad, or from public or private research centers.
L'archive ouverte pluridisciplinaire HAL, est destinée au dépôt et à la diffusion de documents scientifiques de niveau recherche, publiés ou non, émanant des établissements d'enseignement et de recherche français ou étrangers, des laboratoires publics ou privés. 


\title{
Ultra compact High responsivity photodiodes for $>100$ Gbaud applications
}

\author{
C. Caillaud(1), H. Bertin(1), A. Bobin(1), R. Gnanamani(1), (2), N. Vaissiere(1), F. Pommereau (1), J. \\ Decobert(1) and C. Maneux (2)
}

(1) III-V lab, a joint lab between NBLF, TRT and CEA-Leti, christophe.caillaud@3-5lab.fr

(2) IMS Laboratory, University of Bordeaux, CNRS UMR 5218, 33405 Talence, France

\begin{abstract}
We demonstrated ultra-compact waveguide UTC photodiode with bandwidth efficiency product of $36 \mathrm{GHz}$ on $50 \Omega$ load and above $55 \mathrm{GHz}$ on $25 \Omega$ load, which allows to reach a bandwidth above $110 \mathrm{GHz}$ with $0.6 \mathrm{~A} / \mathrm{W}$ responsivity.
\end{abstract}

\section{Introduction}

The fast increase of cloud services leads to a continuous increase of data traffic and transmission experiments are now done at 100 Gbaud and even 200 Gbaud. High bandwidth receiver are of primary importance to limit the complexity of digital signal processing and are widely studied ${ }^{[1-4]}$. A classical method to have an improve HF response is to use a matching load resistor to reduce $\mathrm{RC}$ time constant and reflection due to impedance mismatch. Using this technique, a receiver module using matching load resistor (resulting in $25 \Omega$ effective load) to improve HF response has been demonstrated recently with $145 \mathrm{GHz}$ bandwidth ${ }^{[1]}$ but at the price of a reduced responsivity and a high PDL ( $>4 \mathrm{~dB}$ ). Using the same approach, a bandwidth of $120 \mathrm{GHz}$ with $0.51 \mathrm{~A} / \mathrm{W}$ responsivity ${ }^{[2]}$ and $100 \mathrm{GHz}$ with $0.66 \mathrm{~A} / \mathrm{W}$ responsivitylresponsivity ${ }^{[3]}$ has been achieved. When looking at intrinsic PD performance, without $50 \Omega$ matching resistor, $\approx 0.5 \mathrm{~A} / \mathrm{W}$ with $75 \mathrm{Ghz}$ bandwidth has been demonstrated $[4]$. These diodes however suffer from the length of the input taper $(\approx 1 \mathrm{~mm})$ which increase the overall size of the device.

We have demonstrated in the past short multimode waveguide photodiodes with $0.58 \mathrm{~A} / \mathrm{W}$ responsivity and an intrinsic $3-\mathrm{dB}$ bandwidth of $50 \mathrm{GHz}^{[5]}$. In this paper, we will demonstrate very short photodiodes $\left(0.4 \times 0.5 \mathrm{~mm}^{2} \mathrm{chip}\right.$ size $)$ with a responsivity up to $0.8 \mathrm{~A} / \mathrm{W}$ for $>45 \mathrm{GHz}$ intrinsic bandwidth and $85 \mathrm{GHz}$ on $25 \Omega$ load and up to $0.6 \mathrm{~A} / \mathrm{W}$ for $70 \mathrm{GHz}$ intrinsic bandwidth and $>110 \mathrm{GHz}$ bandwidth with matching resistor.

\section{Photodiode design and fabrication}

The photodiode (PD) is grown on a semiinsulating substrate using MOVPE (metal organic vapor phase epitaxy) The structure comprises $P$ doped InGaAs absorption layer $(0.2 \mu \mathrm{m})$ with a inserted between a $\mathrm{p}+\operatorname{InP}$ barrier layer $(0.5 \mu \mathrm{m})$ and a n- InGaAsP collector layer $(0.4 \mu \mathrm{m})$. This structure, derived from the one described $\mathrm{in}^{[5]}$, used a multimode diluted waveguide to allow an efficient coupling with a lensed optical fiber. The input facet is etched using ICP dry etching, which allows to realize on wafer AR coating and define a lens ${ }^{[6]}$ to increase the lateral coupling tolerance. The photodiode junction is etched using a mixed

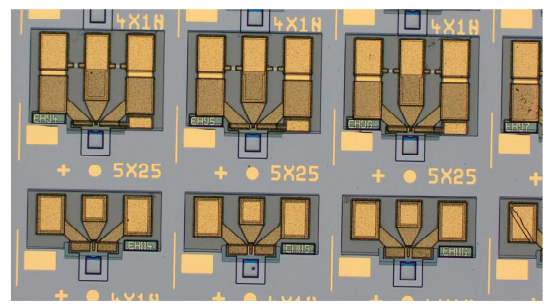

Fig. 1: Optical microscope photograph of UTC wafer with standard photodiode (bottom line) and photodiode with biasing circuit (top line)

of ICP dry etching and wet etching. The main improvements compared to ${ }^{[5]}$ are optimized epitaxial design with a gradient doping profile in $P$ InGaAs absorber to decrease transit time, an improved process to increase responsivity and decrease parasitic capacitance and the optional implementation of biasing circuit comprising a decoupling capacitor and a matching resistor (Fig.1). The photodiodes are very compact $\left(0.4 \times 0.5 \mathrm{~mm}^{2}\right.$ even for devices including integrated biasing circuit) which allows to decrease the individual cost of a photodiode.

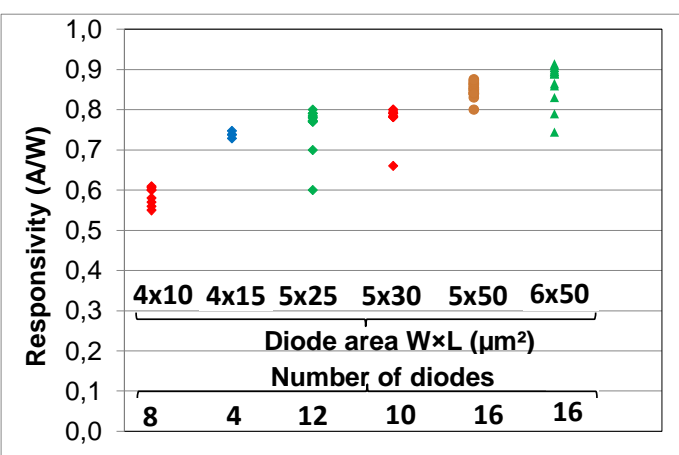

Fig. 2: Responsivity of the UTC photodiode at $1550 \mathrm{~nm}$ with the number of diode measured for each geometry 


\section{Photodiode characteristics}

We implement photodiodes with various dimensions from $4 \times 10 \mu \mathrm{m}^{2}$ to $6 \times 50 \mu \mathrm{m}^{2}$. Typical dark current at $-2 \mathrm{~V}$ bias is few $\mathrm{nA}$ for all diode size which shows the quality of the passivation of the

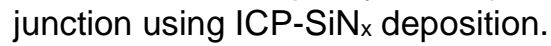

Responsivity measurements are made using a lensed fiber with a mode field diameter (MFD) of $5.5 \mu \mathrm{m}$ and are presented on fig.2. We can notice that the photodiodes presents a high responsivity, up to $0.6 \mathrm{~A} / \mathrm{W}$ for $4 \times 10 \mu \mathrm{m}^{2} \mathrm{PD}$ to $0.91 \mathrm{~A} / \mathrm{W}$ for $6 \times 50 \mu \mathrm{m}^{2} \mathrm{PD}$. For $4 \times 15 \mu \mathrm{m}^{2} \mathrm{PD}$, the responsivity is already significantly improved compared to $4 \times 10 \mu \mathrm{m}^{2} \mathrm{PD}$ and reach $0.73 \mathrm{~A} / \mathrm{W}$ which is very promising to reach simultaneously high bandwidth along with high responsivity.

These measurements, made on several photodiodes (4 to 16 depending on diode geometry, as shown in the graph), also show a good reproducibility of the results. The polarization dependence loss ( $P D L$ ) is very low for all design and stay below $0.2 \mathrm{~dB}$ which is, to our best knowledge, state of the art result for such small photodiodes.

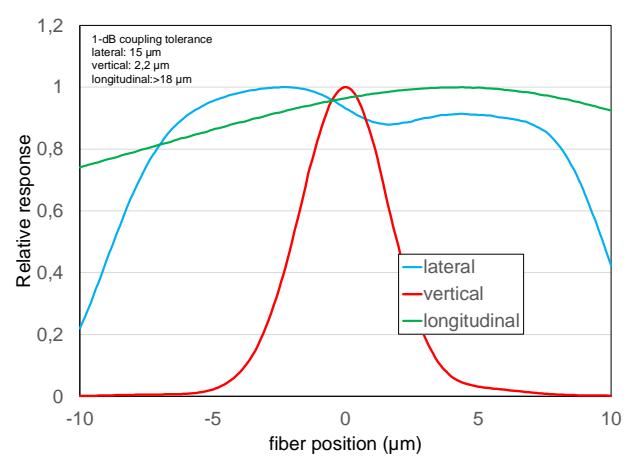

Fig. 3: Coupling tolerance measurements

The use of an integrated lens allows a broad alignment tolerance of $15 \mu \mathrm{m}$ in the lateral direction which simplify the packaging of the photodiode. The tolerance is $2.2 \mu \mathrm{m}$ in the vertical direction and above $18 \mu \mathrm{m}$ in the longitudinal direction.

We then measure the frequency response of our photodiodes using a heterodyne setup. A DC$110 \mathrm{GHz}$ powermeter was used to measure the output HF power of the diode allowing doing a continuous measurement from 0 to $110 \mathrm{GHz}$. Sparameter based correction using the full $S$ parameters of the photodiode, the probe+bias tee and the powermeter, is used to remove the losses of the probe and bias Tee used for the measurement but also to remove the ripple due to the reflection between the photodiode and the powermeter. We first show on Fig. 4 the frequency response of the photodiodes without matching resistor to find the intrinsic bandwidth of



Fig. 4: Influence of the photodiode size on the frequency response

the photodiode on $50 \Omega$ load. The measurement was done at $1 \mathrm{~mA}$ photocurrent and $-1 \mathrm{~V}$ bias. We can notice that the smallest photodiode $\left(4 \times 10 \mu \mathrm{m}^{2}\right)$ present a wide $3 \mathrm{~dB}$ bandwidth of $70 \mathrm{GHz}$ with a responsivity of $0.6 \mathrm{~A} / \mathrm{W}$, resulting in a wide bandwidth-efficiency product of $34 \mathrm{GHz}$ on $50 \Omega$ load. The $4 \times 15 \mu \mathrm{m}^{2}$ one demonstrates an even higher bandwidth-efficiency product of $37 \mathrm{GHz}$ with a $3 \mathrm{~dB}$ bandwidth of $63 \mathrm{GHz}$ and a responsivity of $0.73 \mathrm{~A} / \mathrm{W}$. Our photodiode design is very versatile as we obtain on the same wafer 0.8 A/W responsivity and $46 \mathrm{GHz}$ bandwidth with $5 \times 25 \mu \mathrm{m}^{2} \mathrm{PD}$ and even the bandwidth of very large $6 \times 50 \mu \mathrm{m}^{2} \mathrm{PD}$ is still above $25 \mathrm{GHz}$.

S-parameter measurement allows to extract series resistance and capacitance of the different photodiodes which are respectively $27.8 \Omega$ and $16.6 \mathrm{fF}$ for $4 \times 10 \mu \mathrm{m}^{2}$ photodiode $(123 \mathrm{GHz} \mathrm{RC}$ cut off), $19.5 \Omega$ and $23.1 \mathrm{fF}$ for $4 \times 15 \mu \mathrm{m}^{2}$ photodiode ( $99 \mathrm{GHz} \mathrm{RC}$ cut off), $11.5 \Omega$ and $42.8 \mathrm{fF}$ for $5 \times 25 \mu \mathrm{m}^{2}$ photodiode $(60 \mathrm{GHz} \mathrm{RC}$ cut off). From these measurements, we assess an equivalent frequency corresponding to transit time around $80-85 \mathrm{GHz}$, which is known to be the limiting factor for small diodes. This transit time can easily be improved by reducing collector thickness which is the bandwidth limiting factor.

Fig. 5 presents the influence of the bias voltage on the bandwidth. We can see that even at $\mathrm{OV}$ bias, a wide $3-\mathrm{dB}$ bandwidth of $45 \mathrm{GHz}$ is achieved without responsivity degradation compared to a $-1 \mathrm{~V}$ bias. This is very interesting to simplify photodiode packaging. Then the optimal bias voltage is $-1 \mathrm{~V}$ with $62 \mathrm{GHz}$ bandwidth and the bandwidth decrease to $57 \mathrm{GHz}$ and $53 \mathrm{GHz}$ with respectively -2 and $-3 \mathrm{~V}$ bias voltage. This may results from the electron velocity decreasein III-V semiconductor for electric field is above $\approx 10 \mathrm{kV} / \mathrm{cm}$. This confirms that the transit time in the collector is the major photodiode bandwidth contribution and that the it could be further increased by reducing the 
collector thickness.

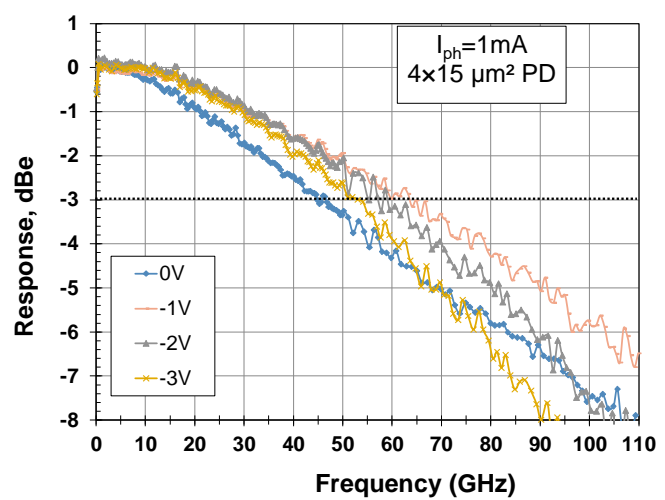

Fig. 5: Influence of the voltage on the frequency response

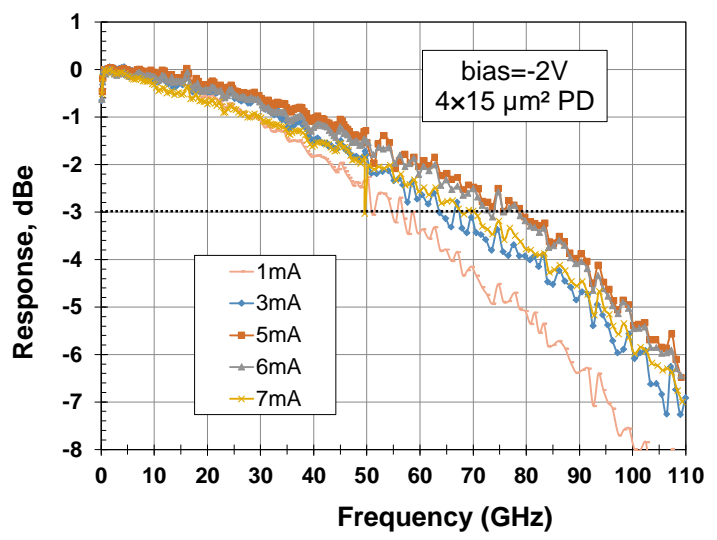

Fig. 6: Influence of the photocurrent on the frequency

UTC are well known for their improved bandwidth under high photocurrent condition, due to negative differential capacitance and electrons overshoot velocity. We measured the frequency response for various photocurrent under $-1,-2$ and $-3 \mathrm{~V}$ bias. Fig.6. shows the results under $-2 \mathrm{~V}$ which are the most interesting: the bandwidth increase from $57 \mathrm{GHz}$ at $1 \mathrm{~mA}$ to $80 \mathrm{GHz}$ at 5 and $6 \mathrm{~mA}$ photocurrent. Interestingly, at $6 \mathrm{~mA}$ photocurrent, the responsivity increase by $17 \%$ compared to $1 \mathrm{~mA}$ photocurrent at $0.85 \mathrm{~A} / \mathrm{W}$ due to increased temperature in InGaAs absorber.

We implement biasing integrated circuit on samples of $5 \times 25$ and $4 \times 10 \mu \mathrm{m}^{2}$ photodiode with decoupling capacitor and matching resistor. Fig.7 shows their frequency response at $1 \mathrm{~mA}$ photocurrent and of the $4 \times 10 \mu \mathrm{m}^{2} \mathrm{PD}$ at $3 \mathrm{~mA}$. We can notice that due to a $25 \Omega$ effective load

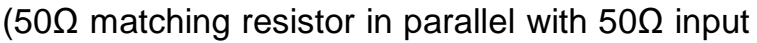
impedance of the powermeter) the bandwidth is greatly enhanced and is now above $86 \mathrm{GHz}$ for $5 \times 25 \mu \mathrm{m}^{2} \mathrm{PD}$ and above $110 \mathrm{GHz}$ for $4 \times 10 \mu \mathrm{m}^{2}$ PD which give records bandwidth-efficiency product of respectively $55 \mathrm{GHz}$ and above $54 \mathrm{GHz}$ on $25 \Omega$ load. With less than 2-dB losses at $110 \mathrm{GHz}$ at $1 \mathrm{~mA}$ and only $1 \mathrm{~dB}$ losses at $3 \mathrm{~mA}$, we expect a $3-\mathrm{dB}$ bandwidth of at least $120 \mathrm{GHz}$ for small $4 \times 10 \mu \mathrm{m}^{2}$ photodiode.
We observe a small overshoot in the frequency response (around $50 \mathrm{GHz}$ for $5 \times 25 \mu \mathrm{m}^{2} \mathrm{PD}$,

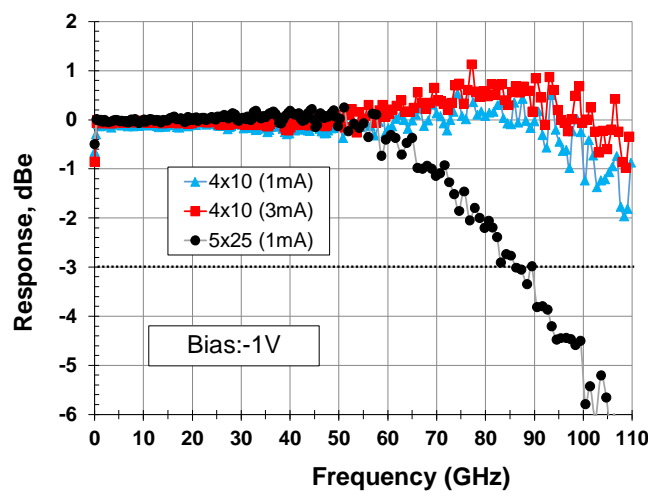

Fig. 7: Frequency response of photodiodes with integrated biasing circuit

around $80 \mathrm{GHz}$ for $4 \times 10 \mu \mathrm{m}^{2} \mathrm{PD}$ ) which could be due to a transmission line inductive behaviour and can explain that we obtain a 3-dB bandwidth above the transit time limit.

\section{Conclusions}

In this paper, we have demonstrated an optimized waveguide UTC design allowing obtaining ultra compact photodiode with very low PDL below $0.2 \mathrm{~dB}$ and a very high efficiencybandwidth product of $36 \mathrm{GHz}$ on $50 \Omega$ load and at least $55 \mathrm{GHz}$ on $25 \Omega$ load. This allows us to realize high speed photodiode with $0.6 \mathrm{~A} / \mathrm{W}$ responsivity and $70 \mathrm{GHz}$ bandwidth on $50 \Omega$ load. This bandwidth is expanded above $110 \mathrm{GHz}$ bandwidth on $25 \Omega$ load leading to a very high $0.8 \mathrm{~A} / \mathrm{W}$ responsivity with $86 \mathrm{GHz}$ bandwidth. This is a promising building block for future communication above 100Gbaud and high speed instrumentation equipment. !

\section{Acknowledgements}

This work was supported partly by the European project H2020 5G-PHOS (no. 761989), http://www.5gphos.eu.

\section{References}

[1] P. Runge et al., "broadband 145ghz photodetector module targeting 200gbaud applications", OFC 2020. paper M2.A1.

[2] A. Beling et al, "miniaturized waveguide-intergated $p$-in photodetector with 120-ghz bandwidth and high responsivity", IEEE Photon. Technol. Lett, Vol.17, no.10; pp2152-2154, 2005.

[3] H.-G. Bach et al, "InP-based waveguide integrated photodetector with $100 \mathrm{GHz}$ bandwidth", IEEE J. Sel. Topics Quantum Elecon.", vol.10 no. 4, pp668-672, 2004.

[4] G. Zhou et al, "high-power inp-based waveguide integrated modified uni-traveling-carrier photodiodes", IEEE J. Lightwave Technol., Vol.35, no.4, pp717-721, 2017. 
[5] M. Achouche et al, "high performance evanescent edge coupled waveguide unitraveling-carrier photodiodes for $>40-\mathrm{gb} / \mathrm{s}$ optical receivers", IEEE Photon. Technol. Lett, Vol.16, no.2; pp584-586, 2004.

[6] M. Achouche et al., " $43 \mathrm{gb} / \mathrm{s}$ balanced photoreceiver using monolithic integrated lensed facet waveguide dual-utc photodiodes" Proc. OECC-ACOFT, WeC-3 (2008). 